\title{
pH exudate test as a method to estimate viability and vigor of Citrus limonia Osbeck seeds ${ }^{1}$
}

\author{
Deived Uilian de Carvalho ${ }^{2 *}$, Denis Santiago da Costa ${ }^{2}$, \\ Maria Aparecida da $\mathrm{Cruz}^{2}$, Jéssica de Lucena Marinho ${ }^{2}$, Ronan Carlos Colombo ${ }^{2}$, \\ Carmen Silvia Vieira Janeiro Neves ${ }^{2}$
}

\begin{abstract}
The $\mathrm{pH}$ exudate is a quick test used to check the seed membranes integrity; however, its performance is limited due to the singularity of each specie requiring adjustments about its methodology. In this sense, the aim of this study was to perform a quick and accurate physiological potential estimation of Citrus limonia Osb. ('Rangpur Lime') seeds through pH exudate test. First, there was carried out the characterization of five seedlots of 'Rangpur Lime' by determination of the thousand seed mass, water content, germination and emergence. Then, a complete randomized experimental design was installed in a factorial scheme: $5 \times 3 \times 2$ (five seedlots, three indicator solutions, and two immersion periods), to evaluate the $\mathrm{pH}$ exudate. The seeds were individually distributed in polypropylene trays, and after the immersion periods, there were taken pictures and analyzed by a numeric scale. Despite the similarity, the emergence test showed to be more efficient for 'Rangpur Lime' seeds comparing to the germination test, because it promoted higher percentage of seedlings. Regarding the $\mathrm{pH}$ exudate test, there were not observed differences between the seedlots for both analysis, visual and image, not being efficient to discriminate lots of 'Rangpur Lime'.
\end{abstract}

Index terms: ‘Rangpur Lime’, propagation, quick tests, seed quality.

\section{Teste do $\mathrm{pH}$ do exsudato como método para estimar a viabilidade e o vigor de sementes de Citrus limonia Osbeck}

\begin{abstract}
RESUMO - O pH do exsudato é um teste rápido utilizado para verificar a integridade das membranas de sementes, porém seu desempenho é limitado devido à singularidade de cada espécie necessitando de ajustes sobre sua metodologia. O objetivo deste estudo foi realizar uma estimativa rápida e precisa do potencial fisiológico de sementes de Citrus limonia Osb. ('Limão Cravo') pelo teste $\mathrm{pH}$ do exsudato. Inicialmente, realizou-se a caracterização de cinco lotes de sementes de 'Limão Cravo’ pela determinação da massa de mil sementes, teor de água, germinação e emergência. Posteriormente, foi instalado um delineamento inteiramente casualizado em esquema fatorial: $5 \times 3 \times 2$ (cinco lotes de sementes, três concentrações de solução indicadora e dois períodos de imersão), para avaliar o $\mathrm{pH}$ do exudato. As sementes foram distribuídas individualmente em bandejas de polipropileno e, após os períodos de imersão, foram fotografadas e analisadas por meio de escala numérica. Apesar da similaridade, o teste de emergência mostrou ser mais eficiente para sementes de 'Limão Cravo' comparado ao teste de germinação, pois promoveu maior percentual de plântulas. Em relação ao teste $\mathrm{pH}$ do exsudato, não foi possível observar diferenças entre lotes de semente para ambas análises, visual e de imagem, não sendo um teste eficiente para discriminar lotes de 'Limão Cravo'.
\end{abstract}

Termos para indexação: 'Limão Cravo', propagação, testes rápidos, qualidade de semente.

\section{Introduction}

The 'Rangpur Lime' (Citrus limonia Osbeck) is the most used rootstock in the Brazilian citrus orchards due to its compatibility to most scion cultivars, satisfactory yield, induction of early-bearing and adequate performance under water deficit condition, presenting substantial importance for the rain-fed Citrus growing area (Mourão Filho et al., 2007;

\footnotetext{
${ }^{1}$ Submitted on 10/27/2017. Accepted for publication on $02 / 05 / 2018$.

${ }^{2}$ Centro de Ciências Agrárias, Universidade Estadual de Londrina, Caixa postal 10.011, 86057-970 - Londrina, PR, Brasil.

${ }^{*}$ Corresponding author $<$ deived10@gmail.com>
} 
Oliveira et al., 2015; Banhos et al., 2016).

For commercial production of rootstock, the propagation by seeds is the main way to obtain new plants to carry out the grafting method. Therefore, the knowledge of the physiologic potential of citrus seeds is fundamental, because it allows information about the potential number of plants produced and establishment of adequate planning, both spatially and temporally (Carvalho et al., 2002a,b; Nakano et al., 2013; Santos et al., 2015).

In this sense, the seed germination is the main characteristic applied to determine the maximum potential of seed lots reach normal seedlings, under optimal development conditions (Brasil, 2009). However, depending on the specie, as citrus, the test can be extended from 34 to 60 days hindering the decisionmaking about seedlots management in terms of sowing or storage (Carvalho and Silva, 2013; Souza et al., 2015).

Thus, the use of quick and accurate test to estimate the potential of germination and vigor is desired to generate information in short period, allowing appropriate seeds destination. In this way, several quick tests can be cited, such as tetrazolium, electrical conductivity and $\mathrm{pH}$ exudate via phenolphthalein (Dode et al., 2013).

The $\mathrm{pH}$ exudate is a quick test used to check the seed membranes integrity, assuming that during the imbibition phase, non-vigorous seeds reorganize the membrane system more slowly than vigorous seeds, resulting in high metabolites release such as sugars, organic acids, and $\mathrm{H}^{+}$ions, which acidify the medium and decrease the water $\mathrm{pH}$ of seed imbibition (Rech et al., 1999; Carvalho et al., 2002a; Santos et al., 2011). Through the data obtained by $\mathrm{pH}$-measuring devices or acid-base indicator solutions, it is possible to evaluate the physiological condition of each seed and, consequently, the physiological potential of lots (Araldi and Coelho, 2015; Alves et al., 2016).

Despite the $\mathrm{pH}$ exudate be a well-known test in the seed technology, it is limited due to the singularity of each specie, which need adjustments about the methodology regarding the imbibition period, the indicator solution concentration, and the evaluation technique. The subjectivity is the most important limitation when performed by acid-base indicator solution, because the results are based on empirical interpretation of the analyst as the tonalities that the exudate solution assumes according to the $\mathrm{pH}$, after addition of the indicator solution.

In this sense, the image analysis is a promising alternative to eliminate this subjectivity, because it allows a quantitative reading of different shades for the same color (pink), giving credibility to the test. Thereby, the aim of this study was to perform a quick and accurate physiological potential estimation of $C$. limonia seeds through $\mathrm{pH}$ exudate test, using both visual and image analysis of the immersion solution.

\section{Material and Methods}

The 'Rangpur Lime' seeds (C. limonia), represented by five seedlots, were obtained at the Seed Germplasm Bank of the Instituto Agronômico do Paraná, Londrina, Brazil, and stored in a refrigerated chamber at $10{ }^{\circ} \mathrm{C}$ until to analysis. Initially, there was carried out the seeds characterization regarding thousand seed mass, water content, germination and emergence in greenhouse according to the following methodologies:

Thousand seed mass: performed by weighing eight replicates of 100 seeds from each lot according to Brasil (2009).

Water content: determined from two samples of 10 seeds, which were weighed and remained in an greenhouse at $105 \pm$ $3{ }^{\circ} \mathrm{C}$ for 24 hours (Brasil, 2009). The results were expressed in percentage, according to the humidity degree at wet base.

Germination test: 200 seeds from each lot, divided into four samples in a complete randomized experimental design, were distributed on germitest paper, moistened with distilled water equivalent to 2.5 times the weight of the non-hydrated substrate. The experimental set was maintained in a germinator model Mangelsdorf regulated at $25 \pm 1{ }^{\circ} \mathrm{C}$ in constant white lighting. The evaluations were carried out each three days, counting the primary root protrusion and the number of normal seedlings according to Brasil (2009). Through the counting data, there were calculated the germination results, expressed in percentage of primary root protrusion, germination (normal seedlings) and germination speed index, calculated according to Maguire (1962).

Seedling emergence in greenhouse: the seeds from each lot, divided into four samples of 50 seeds in a complete randomized experimental design, were sown twice depth of the seed size into sand boxes $(44 \times 30 \times 7 \mathrm{~cm})$ and kept in a greenhouse during 46 days (until complete emergence). There was recorded the number of emerged seedlings weekly, the results were calculated as percentage of total seedlings and emergence speed index, by formula proposed by Maguire (1962). At the end of the test, there was established the fresh and dry matter of normal seedlings by greenhouse method (70 $\pm 2{ }^{\circ} \mathrm{C}$ ) until constant mass (Nakagawa, 1999).

After initial characterization of the lots, a complete randomized experimental design was installed in a factorial scheme: $5 \times 3 \times 2$, using five seedlots of 'Rangpur Lime' combined with three concentration of indicator solutions and two immersion periods, to evaluate the $\mathrm{pH}$ exudate.

To perform the $\mathrm{pH}$ exudate test, a phenolphthalein $\left(\mathrm{C}_{20} \mathrm{H}_{14} \mathrm{O}_{4}\right)$ indicator solution was formulated using $1 \mathrm{~g}$ of phenolphthalein dissolved into $100 \mathrm{~mL}$ of absolute alcohol and $100 \mathrm{~mL}$ of distilled water. Also, three base solutions were formulated by $0.2 \mathrm{~g}, 0.6 \mathrm{~g}$ and $1.0 \mathrm{~g} \mathrm{Na}_{2} \mathrm{CO}_{3}$ dissolved in $100 \mathrm{~mL}$ of distilled 
Table 1. Concentration, $\mathrm{pH}$, and volume of the standard solutions used in the $\mathrm{pH}$ exudate test of Citrus limonia Osbeck seeds at different immersion periods.

\begin{tabular}{|c|c|c|c|c|c|}
\hline \multirow{2}{*}{ Standard solution } & \multicolumn{2}{|c|}{ Concentration $\left(\mathrm{g} . \mathrm{L}^{-1}\right)$} & \multirow{2}{*}{ pH solution } & \multirow{2}{*}{ Volume $(\mu \mathrm{L})$} & \multirow{2}{*}{$\begin{array}{l}\text { Immersion period } \\
\text { (minutes) }\end{array}$} \\
\hline & $\mathrm{C}_{20} \mathrm{H}_{14} \mathrm{O}_{4}$ & $\mathrm{Na}_{2} \mathrm{CO}_{3}$ & & & \\
\hline 1.0 & 5.0 & 10.0 & 11.4 & 200 & 20 and 40 \\
\hline 0.6 & 5.0 & 6.0 & 11.1 & 1.000 & 60 and 80 \\
\hline 0.2 & 5.0 & 2.0 & 10.5 & 1.200 & 20 and 40 \\
\hline
\end{tabular}

water. After formulations, the base solutions $\left(\mathrm{Na}_{2} \mathrm{CO}_{3}\right)$ and the phenolphthalein indicator were mixed in a $1: 1$ ratio to compose three standard solutions.

The seeds were individually distributed in polypropylene trays $(24 \times 12 \mathrm{~cm})$ of 40 alveoli $(10 \mathrm{~mL})$ filled with $5 \mathrm{~mL}$ of distilled water, there was left one alveoli without seed addition taken as control. After preliminary tests, the standard solutions were added in different periods, according to Table 1 .

After the solutions addition and immersion periods, there were taken pictures using a Nikon ${ }^{\circledR}$ D3100 camera and 18-55 $\mathrm{mm}$ lens, at the following settings: ISO $800,1 / 30$ and $\mathrm{f} / 3.5$. The images were analyzed by the Image $J^{\circledR}$ program to quantify the colors through the numeric scale (Figure 1). At first, there was proposed an index, wich was based on the seed and the control mean (index $=$ seed mean - control mean $/$ control mean) varying from zero to 1 according to the color intensity, when closer to zero more pinkish (darker) and when closer to 1 more colorless (lightness), i.e. the vigorous seed did not release exudates (zero) as much as the non-vigorous seed released (1). Next, the indexes were distributed in the following scale, divided by three points: $<0.33$ (index minor than 0.33 ), considered as vigorous seeds; 0.33 -0.66 (index between 0.33 and 0.66 ), representing those with medium vigor; and 0.66 (index greater than 0.66 ), considered as non-vigorous seeds.

Similarly, there was established a parameter to evaluate the seed performance via visual analysis, which the dark pink color represented those seeds with high performance, vigorous seeds; when presented light pink color, it was considered as medium vigor; and when was not observed the pinkish color (colorless), there was considered as non-vigorous seeds. For both, image and visual analysis, the results were expressed as percentage.

All data were submitted to the $\mathrm{R}$ program for analysis of variance and the means were compared by Tukey's test at $5 \%$ of probability. In parallel, there was performed the Pearson correlation.

\section{Results and Discussion}

Regarding seed characteristics, it was observed similar values for most of the lots, except to lot $\mathrm{E}$ that presented the highest mean for thousand seeds mass (Table 2). It must indicate that this lot was

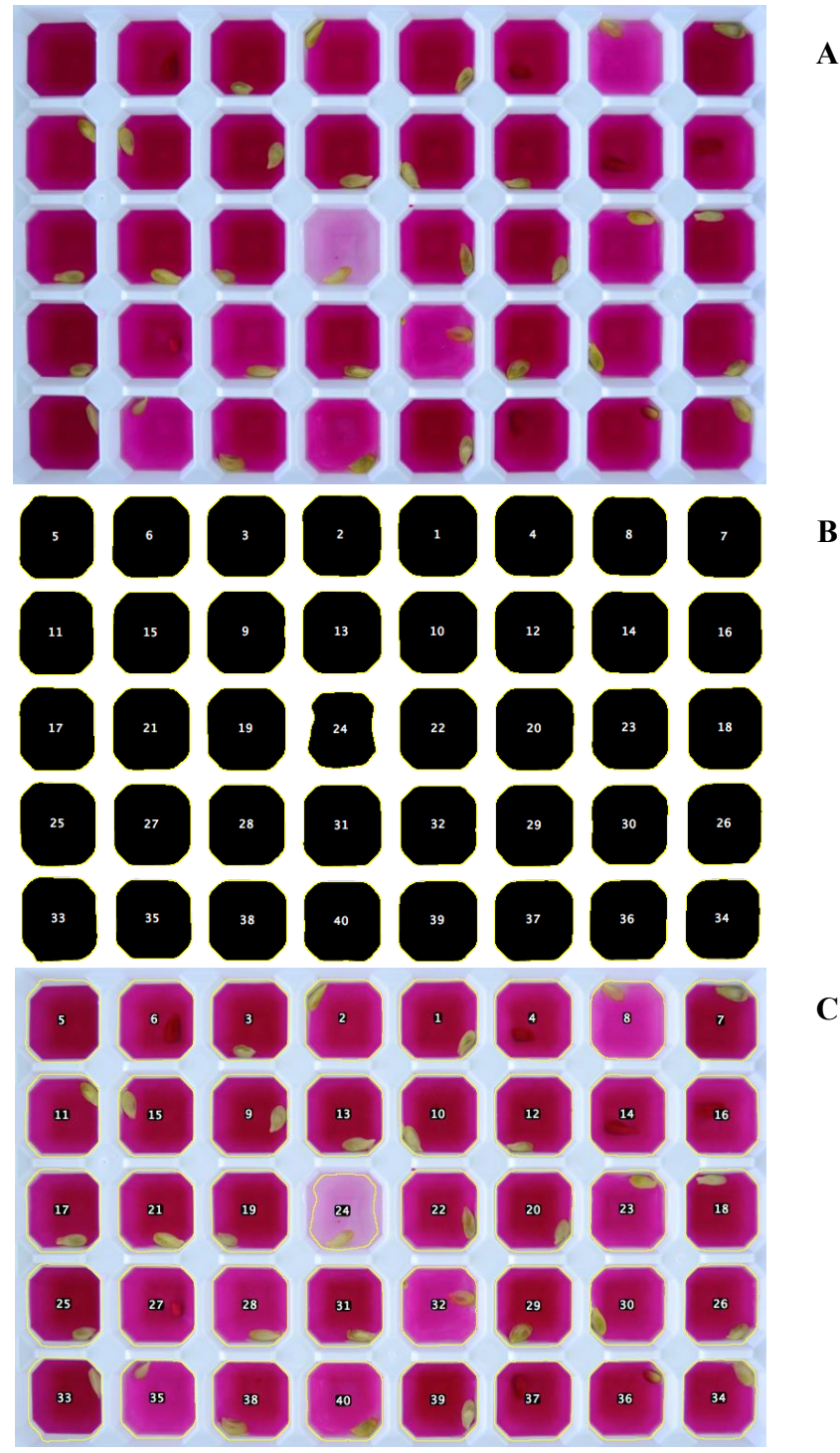

Figure 1. (A) Polypropylene trays containing 'Rangpur Lime' seeds after immersion period of 60 minutes at $0.6\left(\mathrm{C}_{20} \mathrm{H}_{14} \mathrm{O}_{4}+\mathrm{Na}_{2} \mathrm{CO}_{3}\right)$; (B) alveolus delimited by the outlines; $(\mathrm{C})$ alveolus area used to analyze the color intensity, (C-5) alveoli without seed addition, taken as control. 
Table 2. Thousand seed mass (TSM), percentage of water content (WC), primary root protrusion (PRP), germination (Germ), and germination speed index (GSI) in different lots of Citrus limonia seeds.

\begin{tabular}{cccccc}
\hline Lots & TSM $(\mathrm{g})$ & WC $(\%)$ & PRP $(\%)^{*}$ & Germ (\%) & GSI* $^{*}$ \\
\hline A & 53.63 & 13.1 & $82 \mathrm{a}$ & $72 \mathrm{a}$ & $1.62 \mathrm{a}$ \\
$\mathrm{B}$ & 54.02 & 14.8 & $78 \mathrm{ab}$ & $65 \mathrm{ab}$ & $1.57 \mathrm{ab}$ \\
C & 54.29 & 13.5 & $69 \mathrm{~b}$ & $53 \mathrm{bc}$ & $1.34 \mathrm{~b}$ \\
D & 53.87 & 11.5 & $52 \mathrm{c}$ & $43 \mathrm{~cd}$ & $1.02 \mathrm{c}$ \\
E & 67.56 & 14.3 & $43 \mathrm{c}$ & $33 \mathrm{~d}$ & $0.83 \mathrm{c}$ \\
\hline CV (\%) & - & - & 7.76 & 12.43 & 9.78 \\
\hline
\end{tabular}

"Means followed by the same letters in the column do not differ statistically by Tukey's test at 0.05 probability level.

compounded for seeds of large size making the lot heavier, which can influence the seed physiological potential. The water content means were analogous, ranging from 11 to $14 \%$ (3.3 points percent for maximum point) showing that seeds from all lots were in the same metabolic level, which did not interfere to the experimental results.

The germination test variables are also presented at the Table 2, which can be observed a significant difference among the seed lots. The lots A and B did not differ for the variables analyzed, attaining the highest means for the percentage of primary root protrusion (over than $78 \%$ ), germination (greater than $65 \%$ of seedlings), and germination speed index (over than 1.57). However, the seedlots D and $\mathrm{E}$ differed from all, for the percentage of primary root protrusion and germination speed index, reaching just 52 and $43 \%$ for the first variable, 1.02 and 0.83 for the second, respectively. These lots also presented the lowest percentage of germination.

There was noticed corresponding results for the emergence test, wich can be seen at the Table 3. The lots A and B showed to be more vigorous presenting higher means for all characteristics, contrasting to lot $\mathrm{E}$ that attained low means for these variables, especially for the emergence speed index that was almost three times lower than lot A. Consequently, these seedlings may have become more vulnerable to the adverse environmental conditions, because it emerged slowly and spent more time in the initial growth stage (Martins et al., 1999).
Despite the similarity, this test showed to be more efficient for 'Rangpur Lime' seeds comparing to the germination test, because it promoted higher percentage for most of the lots. In this sense, the microorganisms such as fungi and bacteria observed during the germination test, may have interfered to the results as observed by Carvalho et al. (2002a) for citrumelo 'Swingle', since the seeds were maintained in germinator during 46 days at favorable temperature and humidity for mostly microorganism $\left(25^{\circ} \mathrm{C}\right.$ and $\left.95 \%\right)$.

With reference to $\mathrm{pH}$ exudate test, the results are presented at the following tables (Tables 4, 5 and 6). Most of all, there were not observed differences between the seedlots for both analysis, visual and image, just for some specific concentrations and periods.

Respecting to visual analysis, the lot $\mathrm{E}$ presented significantly higher mean for medium vigor seeds at $0.2 \%$ and 20 minutes, around $42 \%$. The lot $\mathrm{E}$ also showed higher percentage of vigorous seeds at $0.6 \%$ in both periods, 60 and 80 minutes. This performance was not observed at $1.0 \%$ and 40 minutes where lot $\mathrm{E}$ reached elevate percentage for non-vigorous seeds, since all the lots had presented low percentage for vigorous and medium vigor seeds. Therefore, it was observed dissimilarity among the characterization results and $\mathrm{pH}$ exudate test for 'Rangpur Lime' and high coefficient of variance, which did not allow the recommendation of any method.

For the image analysis, there was just observed difference

Table 3. Percentage of emergence in greenhouse (EG), emergence speed index (ESI), shoot fresh matter (SFM), and shoot dry matter (SDM) of different lots of Citrus limonia seeds.

\begin{tabular}{ccccc}
\hline Lots & EG (\%) & ESI & SFM (g) (g.seedling $\left.)^{-1}\right)^{*}$ & SDM (g) (g.seedling $\left.{ }^{-1}\right)^{*}$ \\
\hline $\mathrm{A}$ & $88 \mathrm{a}$ & $1.49 \mathrm{a}$ & $5.01 \mathrm{a}$ & $1.64 \mathrm{a}$ \\
$\mathrm{B}$ & $80 \mathrm{ab}$ & $1.34 \mathrm{ab}$ & $4.57 \mathrm{a}$ & $1.39 \mathrm{a}$ \\
$\mathrm{C}$ & $62 \mathrm{bc}$ & $1.14 \mathrm{bc}$ & $4.11 \mathrm{ab}$ & $1.28 \mathrm{ab}$ \\
$\mathrm{D}$ & $58 \mathrm{c}$ & $0.93 \mathrm{c}$ & $2.90 \mathrm{~b}$ & $0.94 \mathrm{~b}$ \\
$\mathrm{E}$ & $32 \mathrm{~d}$ & $0.49 \mathrm{~d}$ & $1.65 \mathrm{c}$ & $0.49 \mathrm{c}$ \\
\hline CV $(\%)$ & 12.63 & 12.49 & 15.28 & 17.20 \\
\hline
\end{tabular}

"Means followed by the same letters in the column do not differ statistically by Tukey's test at 0.05 probability level. 
Table 4. Visual analysis, expressed in percentage, of $\mathrm{pH}$ exudate at different concentrations and periods in different lots of Citrus limonia seeds.

\begin{tabular}{|c|c|c|c|c|c|c|}
\hline Lots & A & $\mathrm{B}$ & $\mathrm{C}$ & $\mathrm{D}$ & $\mathrm{E}$ & CV (\%) \\
\hline \multicolumn{7}{|c|}{$0.2 \%-20$ minutes } \\
\hline VIG & $38.1^{\mathrm{ns}}$ & 46.2 & 43.6 & 44.9 & 32.1 & 31.5 \\
\hline $\mathrm{MDV}^{*}$ & $16.7 \mathrm{~b}$ & $19.2 \mathrm{~b}$ & $21.8 \mathrm{~b}$ & $23.1 \mathrm{~b}$ & $42.3 \mathrm{a}$ & 13.2 \\
\hline NVIG & $44.9^{\mathrm{ns}}$ & 34.6 & 34.6 & 32.0 & 25.6 & 35.7 \\
\hline \multicolumn{7}{|c|}{$0.2 \%-40$ minutes } \\
\hline VIG & $24.4^{\mathrm{ns}}$ & 25.6 & 34.6 & 26.9 & 12.8 & 36.2 \\
\hline MDV & $17.9^{\mathrm{ns}}$ & 21.8 & 19.2 & 23.1 & 30.8 & 39.0 \\
\hline NVIG & $57.7^{\mathrm{ns}}$ & 52.6 & 46.2 & 50.0 & 56.4 & 27.4 \\
\hline \multicolumn{7}{|c|}{$0.6 \%-60$ minutes } \\
\hline $\mathrm{VIG}^{*}$ & $76.9 \mathrm{ab}$ & $73.0 \mathrm{c}$ & $83.4 \mathrm{ab}$ & $76.9 \mathrm{ab}$ & $97.4 \mathrm{a}$ & 6.7 \\
\hline $\mathrm{MDV}^{*}$ & $16.7 \mathrm{ab}$ & $24.4 \mathrm{a}$ & $12.8 \mathrm{ab}$ & $19.3 \mathrm{a}$ & $2.6 \mathrm{~b}$ & 25.7 \\
\hline NVIG & $6.4^{\mathrm{ns}}$ & 2.6 & 3.8 & 3.8 & 0.0 & 79.9 \\
\hline \multicolumn{7}{|c|}{$0.6 \%-80$ minutes } \\
\hline $\mathrm{VIG}^{*}$ & $62.8 \mathrm{~b}$ & $65.4 \mathrm{~b}$ & $69.2 \mathrm{~b}$ & $67.9 \mathrm{~b}$ & $87.2 \mathrm{a}$ & 4.5 \\
\hline $\mathrm{MDV}^{*}$ & $26.9 \mathrm{a}$ & $29.5 \mathrm{a}$ & $25.6 \mathrm{a}$ & $27.0 \mathrm{a}$ & $12.8 \mathrm{~b}$ & 8.8 \\
\hline NVIG & $10.3^{\mathrm{ns}}$ & 5.1 & 5.2 & 5.1 & 0.0 & 70.9 \\
\hline \multicolumn{7}{|c|}{$1.0 \%-20$ minutes } \\
\hline VIG & $23.1^{\mathrm{ns}}$ & 32.1 & 24.4 & 25.6 & 19.2 & 14.2 \\
\hline MDV & $9.0^{\mathrm{ns}}$ & 14.1 & 6.4 & 10.3 & 14.1 & 60.1 \\
\hline NVIG & $67.9^{\mathrm{ns}}$ & 53.8 & 69.2 & 64.1 & 66.7 & 12.9 \\
\hline \multicolumn{7}{|c|}{$1.0 \%-40$ minutes } \\
\hline $\mathrm{VIG}^{*}$ & $2.6 \mathrm{~b}$ & $16.7 \mathrm{a}$ & $6.4 \mathrm{ab}$ & $9.0 \mathrm{ab}$ & $2.6 \mathrm{~b}$ & 42.3 \\
\hline $\mathrm{MDV}^{*}$ & $3.8 \mathrm{ab}$ & $11.5 \mathrm{a}$ & $5.1 \mathrm{ab}$ & $9.0 \mathrm{a}$ & $0.0 \mathrm{~b}$ & 36.0 \\
\hline NVIG $^{*}$ & $93.6 \mathrm{ab}$ & $71.8 \mathrm{c}$ & $88.5 \mathrm{ab}$ & $82.0 \mathrm{bc}$ & $97.4 \mathrm{a}$ & 4.4 \\
\hline
\end{tabular}

VIG - Vigorous; MDV - Medium vigor; NVIG - Non-vigorous. "Means followed by the same letters in the row do not differ statistically by Tukey's test at 0.05 probability level. ${ }^{\text {ns }}$ - non-significative.

Table 5. Image analysis of $\mathrm{pH}$ exudate at different concentration and periods in different lots of Citrus limonia seeds, expressed in percentage.

\begin{tabular}{|c|c|c|c|c|c|c|}
\hline Lots & A & B & $\mathrm{C}$ & $\mathrm{D}$ & $\mathrm{E}$ & CV (\%) \\
\hline \multicolumn{7}{|c|}{$0.2 \%-20$ minutes } \\
\hline VIG & $24.4^{\mathrm{ns}}$ & 35.9 & 18.0 & 15.4 & 61.5 & 51.0 \\
\hline MDV & $38.5^{\mathrm{ns}}$ & 35.9 & 42.3 & 43.6 & 38.5 & 25.6 \\
\hline NVIG & $37.1^{\mathrm{ns}}$ & 28.2 & 39.7 & 41.0 & 0.0 & 62.8 \\
\hline \multicolumn{7}{|c|}{$0.2 \%-40$ minutes } \\
\hline VIG & $6.4^{\mathrm{ns}}$ & 15.4 & 11.6 & 5.1 & 67.9 & 103.5 \\
\hline MDV & $61.5^{\mathrm{ns}}$ & 51.3 & 47.4 & 51.3 & 32.1 & 52.5 \\
\hline NVIG & $32.1^{\mathrm{ns}}$ & 33.3 & 41.0 & 43.6 & 0.0 & 77.3 \\
\hline \multicolumn{7}{|c|}{$0.6 \%-60$ minutes } \\
\hline VIG & $42.3^{\mathrm{ns}}$ & 84.6 & 44.9 & 88.5 & 96.2 & 52.4 \\
\hline MDV & $38.5^{\mathrm{ns}}$ & 7.7 & 41.0 & 10.2 & 3.8 & 121.8 \\
\hline NVIG & $19.2^{\mathrm{ns}}$ & 7.7 & 14.1 & 1.3 & 0.0 & 155.2 \\
\hline \multicolumn{7}{|c|}{$0.6 \%-80$ minutes } \\
\hline VIG & $67.9^{\mathrm{ns}}$ & 59.0 & 87.2 & 73.1 & 82.0 & 17.2 \\
\hline MDV & $16.7^{\mathrm{ns}}$ & 26.9 & 7.7 & 23.1 & 15.4 & 74.7 \\
\hline NVIG & $15.4^{\mathrm{ns}}$ & 14.1 & 5.1 & 3.8 & 2.6 & 85.0 \\
\hline \multicolumn{7}{|c|}{$1.0 \%-20$ minutes } \\
\hline $\mathrm{VIG}^{*}$ & $14.1 \mathrm{~b}$ & $75.6 \mathrm{ab}$ & $30.8 \mathrm{ab}$ & $51.3 \mathrm{ab}$ & $100 \mathrm{a}$ & 38.8 \\
\hline $\mathrm{MDV}^{*}$ & $85.9 \mathrm{a}$ & $24.4 \mathrm{ab}$ & $69.2 \mathrm{ab}$ & $48.7 \mathrm{ab}$ & $0.0 \mathrm{~b}$ & 46.2 \\
\hline NVIG & $0.0^{\mathrm{ns}}$ & 0.0 & 0.0 & 0.0 & 0.0 & - \\
\hline \multicolumn{7}{|c|}{$1.0 \%-40$ minutes } \\
\hline $\mathrm{VIG}$ & $42.3^{\mathrm{ns}}$ & 100 & 80.8 & 82.1 & 100 & 23.8 \\
\hline MDV & $57.7^{\mathrm{ns}}$ & 0.0 & 19.2 & 17.9 & 0.0 & 101.7 \\
\hline NVIG & $0.0^{\mathrm{ns}}$ & 0.0 & 0.0 & 0.0 & 0.0 & - \\
\hline
\end{tabular}

VIG - Vigorous $(<0.33)$; MDV - Medium vigor $(0.33-0.66)$; NVIG - Non-vigorous $(>0.66)$. "Means followed by the same letters in the row do not differ statistically by Tukey's test at 0.05 probability level. ${ }^{\text {ns }}-$ non-significative. 
between the lots at $1.0 \%$ and 20 minutes. The lot $\mathrm{A}$ had most presented medium vigor seeds differently to lot $\mathrm{E}$ that presented only vigorous seeds, contradicting to the germination and emergence results. One hypothesis about the image analysis was that it could reduce the subjectivity promoted by visual method by given a quantitative result for each seed, however it was not observed in this research.

These results (Tables 4 and 5) corroborate to Santos et al. (2011) relating that the $\mathrm{pH}$ exudate was not efficient to part lots of soybean seeds in different vigor levels just as Barboza et al. (2014), which suggested that this test was not effective to analyze the massive viability and vigor of Guazuma ulmifolia seeds because it did not correlate to the emergence test, as seen in this study.

However, Amaral and Peske (2000), Cabrera and Peske (2002), and Alves et al. (2016) found positive correlation between the $\mathrm{pH}$ exudate and germination/emergence tests for wheat, corn and cramble seeds. In this way, this test is not recommended at these conditions to analyze the viability and vigor of $C$. limonia seeds, requiring more research about this specie to adjust the best concentration (indicator solution) and immersion periods of the seeds.

According to the Pearson correlation, there were not observed significance at 0.05 of probability for the analyzed characteristics, showing that $\mathrm{pH}$ exudate does not correspond to the germination and emergence test (Table 6).

The methodology was conducted correctly during the $\mathrm{pH}$ exudate test, but did not achieve the expected results to measure the 'Rangpur Lime' seeds quality, probably because of the seed coat that surrounds the seed. The citrus seed characterizes to present double seed coat, an outer coat derived from the outer integument and an inner seed coat, very compact consisting of the remnants of inner integument, nucellus and endosperm (Koltunow et al., 1995).

This implies that these tissues hinder the seeds to exude quickly, requiring more time to notice their real performance during the $\mathrm{pH}$ exudate test. Another possibility would be the extraction of these tissues before to carry the test out.

Table 6. Pearson correlation (Coefficient of simple correlation) between primary root protrusion (PRP), germination (Germ), germination speed index (GSI), emergence in greenhouse (EG), emergence speed index (ESI), shoot fresh matter (SFM), and shoot dry matter (SDM) of vigorous and medium vigor of Citrus limonia seeds, according to exudate $\mathrm{pH}$ at different concentration and periods at the visual and image analysis.

\begin{tabular}{|c|c|c|c|c|c|c|c|c|}
\hline Treat. & Classification & $\mathrm{PRP}^{\mathrm{ns}}$ & Germ $^{\text {ns }}$ & $\mathrm{GSI}^{\mathrm{ns}}$ & $\mathrm{EG}^{\mathrm{ns}}$ & $\mathrm{ESI}^{\mathrm{ns}}$ & $\mathrm{SFM}^{\mathrm{ns}}$ & $\mathrm{SDM}^{\mathrm{ns}}$ \\
\hline \multicolumn{9}{|c|}{ 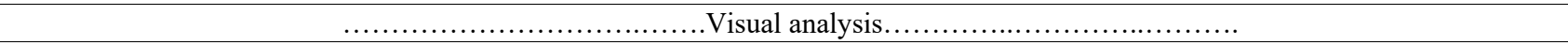 } \\
\hline $0.2 \%$ & VIG & -0.360 & -0.347 & -0.524 & -0.050 & -0.128 & -0.307 & -0.348 \\
\hline $20 \mathrm{~min}$ & VIG+MDV & -0.163 & -0.349 & -0.396 & 0.116 & -0.043 & -0.454 & -0.489 \\
\hline $0.2 \%$ & VIG & -0.267 & -0.146 & -0.241 & -0.128 & -0.175 & -0.222 & -0.302 \\
\hline $40 \mathrm{~min}$ & VIG+MDV & -0.463 & -0.273 & -0.491 & -0.064 & -0.128 & -0.185 & -0.243 \\
\hline $0.6 \%$ & VIG & -0.055 & 0.357 & 0.429 & -0.024 & -0.030 & 0.213 & 0.114 \\
\hline $60 \mathrm{~min}$ & VIG+MDV & -0.186 & 0.166 & 0.206 & -0.278 & -0.179 & 0.249 & 0.194 \\
\hline $0.6 \%$ & VIG & -0.395 & 0.141 & -0.010 & -0.408 & -0.254 & 0.309 & 0.235 \\
\hline $80 \mathrm{~min}$ & $\mathrm{VIG}+\mathrm{MDV}$ & -0.056 & 0.062 & 0.244 & -0.131 & -0.122 & 0.061 & 0.019 \\
\hline $1.0 \%$ & VIG & -0.323 & -0.001 & -0.375 & -0.024 & -0.021 & 0.005 & -0.051 \\
\hline $20 \mathrm{~min}$ & $\mathrm{VIG}+\mathrm{MDV}$ & -0.163 & -0.157 & -0.272 & 0.011 & -0.088 & -0.328 & -0.400 \\
\hline $1.0 \%$ & VIG & -0.332 & -0.102 & -0.472 & -0.093 & -0.077 & -0.075 & -0.121 \\
\hline $40 \mathrm{~min}$ & VIG+MDV & 0.052 & -0.029 & -0.052 & 0.261 & 0.075 & -0.370 & -0.444 \\
\hline \multicolumn{9}{|c|}{ 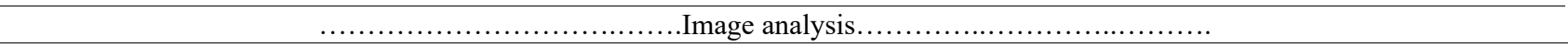 } \\
\hline $0.2 \%$ & VIG & 0.084 & -0.097 & -0.027 & 0.264 & 0.046 & -0.472 & -0.550 \\
\hline $20 \mathrm{~min}$ & VIG+MDV & -0.159 & -0.292 & -0.293 & 0.095 & -0.065 & -0.429 & -0.482 \\
\hline $0.2 \%$ & VIG & -0.423 & -0.025 & -0.307 & 0.039 & 0.011 & 0.133 & 0.083 \\
\hline $40 \mathrm{~min}$ & VIG+MDV & -0.093 & -0.261 & -0.243 & 0.165 & -0.027 & -0.467 & -0.525 \\
\hline $0.6 \%$ & VIG & -0.314 & 0.328 & 0.139 & -0.446 & -0.205 & 0.554 & 0.504 \\
\hline $60 \mathrm{~min}$ & VIG+MDV & -0.164 & 0.347 & 0.301 & -0.338 & -0.155 & 0.470 & 0.420 \\
\hline $0.6 \%$ & VIG & 0.197 & 0.405 & 0.571 & 0.267 & 0.144 & 0.058 & -0.035 \\
\hline $80 \mathrm{~min}$ & VIG+MDV & -0.015 & 0.125 & 0.281 & -0.117 & -0.042 & 0.276 & 0.288 \\
\hline $1.0 \%$ & VIG & 0.153 & 0.327 & 0.214 & 0.050 & 0.118 & 0.248 & 0.247 \\
\hline $20 \mathrm{~min}$ & VIG+MDV & - & - & - & - & - & - & - \\
\hline $1.0 \%$ & VIG & -0.075 & -0.482 & -0.537 & 0.072 & 0.019 & -0.296 & -0.208 \\
\hline $40 \mathrm{~min}$ & VIG+MDV & - & - & - & - & - & - & - \\
\hline
\end{tabular}

VIG - Vigorous; MDV - Medium vigor. n.s. - non-significative. 
As reported before, this test did not present comparable result to the germination and emergence tests, likely because of the time. In both test, the seeds remained more than 45 days surrounded by germitest paper and sand, for germination and emergence test respectively. Bewley et al. (2013) suggest that microbial action can mediate in the opening of impermeable seed coats. Under these circumstances, the tissues surrounding the embryos, zygotic and nucellar, could have been slowly degraded by microorganisms present into the substrates, increasing the seed permeability to water and gases and consequently allowing its germination and emergence. However, this effect was not observed for the $\mathrm{pH}$ exudate test.

In general, there were observed high coefficient of variation in both analysis (visual and image), which indicates a substantial range in the dataset. Also, the membrane permeability test at different concentration solutions and periods did not correlate to the germination and emergence tests in both analysis, not allowing to perform the relation between visual and image analyzes, since these analyses were not correlated to any test.

\section{Conclusions}

The 'Rangpur Lime' cannot have their seed physiological potential, quickly and accurately, determined by the $\mathrm{pH}$ exudate test under these experimental conditions, through visual method or even when it is used a quantitative image analysis.

\section{References}

ALVES, C.Z.; RODRIGUES, L.A.; REGO, C.H.Q.; SILVA, J.B. pH of exudate test in the physiological quality of crambe seeds. Ciencia Rural, v.46, n.6, p.1014-1018, 2016. http://www.scielo.br/pdf/cr/ v46n6/1678-4596-cr-46-06-01014.pdf

AMARAL, A.S.; PESKE, S.T. Testes para avaliação rápida da qualidade fisiológica de sementes de trigo. Revista Brasileira de Agrociência, v.6, n.1, p.12-15, 2000. http://www2.ufpel.edu.br/ faem/agrociencia/v6n1/artigo02.pdf

ARALDI, C.G.; COELHO, C.M.M. pH do Exsudato na avaliação da viabilidade de sementes de Araucaria angustifolia. Floresta e Ambiente, v.22, n.3, p.426-433, 2015. http://www.scielo.br/pdf/ floram/v22n3/2179-8087-floram-22-3-426.pdf

BANHOS, O.F.A.A.; CARVALHO, B.M.O.; VEIGA, E.B.; BRESSAN, A.C.G.; TANAKA, F.A.O; HABERMANN, G. Aluminum-induced decrease in $\mathrm{CO}_{2}$ assimilation in 'Rangpur' lime is associated with low stomatal conductance rather than low photochemical performances. Scientia Horticulturae, v.205, p.133140, 2016. http://dx.doi.org/10.1016/j.scienta.2016.04.021
BARBOZA, V.R.S.; PINTO, M.A.D.S.C.; FREIRE, C.S.; OLIVEIRA, C.K.S. Potencial fisiológico de sementes de Guazuma ulmifolia lam. através do teste do $\mathrm{pH}$ do exsudato. Enciclopédia Biosfera, v.10, n.18, p.2327-2335, 2014. http://conhecer.org.br/ enciclop/2014a/AGRARIAS/potencial\%20fisiologico.pdf

BEWLEY, J.D.; BRADFORD, K.J.; HILHORST, H.W.M.; NONOGAKI, H. Seeds: physiology of development, germination and dormancy. 3.ed. New York: Springer, 2013. 392p.

BRASIL. Ministério da Agricultura, Pecuária e Abastecimento. Regras para análise de sementes. Ministério da Agricultura, Pecuária e Abastecimento. Secretaria de Defesa Agropecuária. Brasília: MAPA/ACS, 2009. 395p.

CABRERA, A.C.; PESKE, S.T. Testes do $\mathrm{pH}$ do exsudato para sementes de milho. Revista Brasileira de Sementes, v.24, n.1, p.134140, 2002. http://www.scielo.br/pdf/rbs/v24n1/v24n1a19.pdf

CARVALHO, J.A.; VON PINHO, E.V.R.; OLIVEIRA, J.A.; GUIMARÃES, R.M.; BONOME, L.T. Testes rápidos para avaliação da qualidade fisiológica de sementes de Citromelo swingle. Revista Brasileira de Sementes, v.24, n.1, p.263-270, 2002a. http://www. scielo.br/pdf/rbs/v24n1/v24n1a37.pdf

CARVALHO, J.A.; VON PINHO, E.V.R.; OLIVEIRA, J.A.; GUIMARÃES, R.M.; BONOME, L.T. Qualidade de sementes de limão-cravo (Citrus limonia Osbeck) durante o armazemanento. Revista Brasileira de Sementes, v.24, n.1, p.286-298, 2002b. http:// dx.doi.org/10.1590/S0101-31222002000100040

CARVALHO, S.A.; SILVA, L.F.C. Monitoring the viability of citrus rootstocks seeds stored under refrigeration. Revista Brasileira de Fruticultura, v.35, n.1, p.238-245, 2013. http://www.scielo.br/pdf/ $\mathrm{rbf} / \mathrm{v} 35 \mathrm{n} 1 / 27 . \mathrm{pdf}$

DODE, J.S.; MENEGHELLO, G.E.; TIMM, F.C.; MORAES, D.M.; PESKE, S.T. Teste de respiração em sementes de soja para avaliação da qualidade fisiológica. Ciência Rural, v.43, n.2, p.193-198, 2013. http://www.scielo.br/pdf/cr/v43n2/a3613cr5997.pdf

KOLTUNOW, A.M.; SOLTYS, K.; NITO, N.; McCLURE, S. Anther, ovule, seed, and nucellar embryo development in Citrus sinensis cv. Valencia. Canadian Journal of Botany, n.73, p.15671582, 1995. http://www.nrcresearchpress.com/doi/abs/10.1139/b95170\#.WRbsohiZNo4

MAGUIRE, J.D. Speed of germination-aid in selection and evaluation for seedling emergence and vigour. Crop Science, v.2, n.2, p.176-177, 1962. https://dl.sciencesocieties.org/publications/cs/ abstracts/2/2/CS0020020176

MARTINS, C.C.; NAKAGAWA, J.; BOVI, M.L. Efeito da posição da semente no substrato e no crescimento inicial das plântulas de palmito-vermelho (Euterpe espiritosantensis Fernades - Palmae). Revista Brasileira de Sementes, v.21, n.1, p.164-173, 1999. http:// dx.doi.org/10.17801/0101-3122/rbs.v21n1p164-173

MOURÃO FILHO, F.A.A.; ESPINOZA-NÚÑEZ, E.; STUCHI, E.S.; ORTEGA, E.M.M. Plant growth, yield, and fruit quality of 'Fallglo' and 'Sunburst' mandarins on four rootstocks. Scientia Horticulturae, v.114, p.45-49, 2007. https://doi.org/10.1016/j.scienta.2007.05.007 
NAKAGAWA, J. Testes de vigor baseados no desempenho de plântulas. In: KRZYZANOWSKI, F.C.; VIEIRA, R.D.; FRANÇANETO, J.B. (Ed.). Vigor de sementes: conceitos e testes. Londrina: ABRATES, 1999. cap.2, p.1-24.

NAKANO, M.; KIGOSHI, K.; SHIMIZU, T.; ENDO, T.; SHIMADA, T.; FUJII, H.; OMURA, M. Characterization of genes associated with polyembryony and in vitro somatic embryogenesis in Citrus. Tree Genetics \& Genomes, v. 9, n. 3, p.795-803, 2013. https://doi.org/10.1007/s11295-013-0598-8

OLIVEIRA, T.M.; SILVA, F.R.S.; BONATTO, D.; NEVES, D.M.; MORILLON, R.; MASERTI, B.E.; COELHO FILHO, M.A.; COSTA, M.G.C.; PIROVANI, C.P.; GESTEIRA, A.S. Comparative study of the protein profiles of Sunki mandarin and Rangpur lime plants in response to water deficit. BMC Plant Biology, v.15, p.6985, 2015. http://dx.doi.org/10.1186/s12870-015-0416-6

RECH, E.G.; VILLELA, F.A.; TILLMANN, M.A. Avaliação rápida da qualidade fisiológica de sementes de ervilha. Revista Brasileira de Sementes, v.21, n.2, p.1-9, 1999. http://dx.doi.org/10.17801/0101$3122 /$ rbs.v21n2p1-9
SANTOS, J.F.; ALVARENGA, R.O.; TIMÓTEO, T.S.; CONFORTO, E.C.; MARCOS-FILHO, J.; VIEIRA, R.D. Avaliação do potencial fisiológico de lotes de sementes de soja. Revista Brasileira de Sementes, v.33, n.4, p.743-751, 2011. http://www.scielo.br/pdf/rbs/ v33n4/16.pdf

SANTOS, C.Q.; GIRARDI, E.A.; VIEIRA, E.L.; LEDO, C.A.; SOARES FILHO, W.D. Tamanho ótimo de amostras de frutos e de sementes para determinação da poliembrionia em citros. Revista Brasileira Fruticultura, v.7, n.1, p.172-178, 2015. http://dx.doi. org/10.1590/0100-2945-063/14

SOUZA, J.M.A.; MODESTO, J.H.; LEONEL, S.; GONÇALVES, B.H.L.; FERRAZ, R.A. Caracterização física e química dos frutos nos diferentes quadrantes da planta e germinação de sementes do portaenxerto cítrico tangerineira 'Sunki'. Bioscience Journal, v.31, n.2, p.425-432, 2015. http://dx.doi.org/10.14393/BJ-v31n2a2015-22363 